\title{
Abortion, contraceptive use, and adolescent pregnancy among first-year medical students at a major public university in Mexico City
}

\author{
Adriana Ortiz-Ortega, ${ }^{1}$ Guadalupe García de la Torre, ${ }^{2}$ Fernando Galván, ${ }^{2}$ \\ Patricia Cravioto, ${ }^{3}$ Francisco Paz, ${ }^{4}$ Claudia Díaz-Olavarrieta, ${ }^{4,5}$ \\ Charlotte Ellertson, ${ }^{5}$ and Alejandro Cravioto $^{2}$
}

ABSTRACT Objective. If properly trained, medical students could become future opinion leaders in health policy and could help the public to understand the consequences of unwanted pregnancies and of abortions. The objective of this study was to analyze the frequency of unwanted pregnancies and induced abortions that had occurred among women who were first-year medical students at a major public university in Mexico City and to compare the experiences of those women with the experiences of the general population of Mexican females aged 15 to 24. Methods. In 1998 we administered a cross-sectional survey to all the first-year medical students at the National Autonomous University of Mexico, which is the largest university in Latin America. For this study we analyzed 549 surveys completed by female students.

Results. Out of the 549 women, 120 of them (22\%) had been sexually active at some point. Among those 120 sexually active students, 100 of them (83\%) had used a contraceptive method at some time, and 19 of the 120 (16\%) had been pregnant. Of those 19 women who had been pregnant, 10 of them had had an illegal induced abortion (in Mexico, abortions are illegal except under a small number of extenuating circumstances). The reported abortion rate among the female medical students, $2 \%$, was very low in comparison with the $11 \%$ rate for women of similar ages in the Mexican general population.

Conclusions. The lower incidence of abortion among the female medical students indicates that when young Mexican women have access to medical information and are highly motivated to avoid unintended pregnancy and abortion, they can do so.

Key words Abortion, induced; adolescent; pregnancy; contraception; students, medical; Mexico.

Unwanted pregnancy is a serious public health problem in Mexico and

El Colegio de Mexico, Mexico City, Mexico.

National Autonomous University of Mexico, Mexico City, Mexico.

Ministry of Health, Mexico City, Mexico.

National Institute of Neurology, Mexico City, Mexico.

The Population Council, Mexico City, Mexico. Send correspondence to: Claudia Díaz-Olavarrieta, Population Council, Panzacola \# 62-102, 04000, Mexico City, Mexico; telephone: (525) 59-99-86-66; fax: (525) 56-54-12-26; e-mail: cdiaz@popcouncil. org.mx also in much of the rest of Latin America, where it is particularly common among young people. It is estimated that $60 \%$ of the unintended pregnancies around the world take place among adolescents (defined here as persons aged 10-24) (1). In the developing world, two million adolescents obtain abortion services each year, mostly under unsafe, illegal circumstances (2).

In Mexico, with a total population of 97 million and with $51 \%$ of all females being of child-bearing age (15-44 years old), good-quality direct measurements of the number of abortions performed are not available. However, one set of indirect estimates places the number at 500000 per year (3), even though abortions are illegal except under a small number of extenuating circumstances. For an abortion to be authorized, a woman must obtain permission from a court. As of 2003 most Mexican states (95\%) considered rape 
an extenuating circumstance, and $87 \%$ of the states allowed a woman to have an abortion if her life was at risk. Although women who undergo an unauthorized abortion are rarely imprisoned, the jail sentence could range from 6 months to 5 years. Similarly, physicians who provide abortions in circumstances not permitted by the law could be penalized with a jail sentence of 1 to 8 years.

The most significant recent abortion reform in Mexico occurred in 1998 in Mexico City, whose penal code provisions on abortion had not been changed since 1931. Under the new Mexico City provisions, abortion is permitted under the following extenuating circumstances: (1) when the pregnancy results from nonconsensual artificial insemination; (2) when the woman's health is endangered, according to the medical opinion of at least two physicians; (3) when at least two medical specialists assess the case and report a congenital abnormality; and (4) when the pregnancy is the result of rape. The role of physicians is key with abortion practices in both public and private hospitals, since in all cases a medical committee has to evaluate the court order asking that the woman be allowed to undergo an abortion.

There are several reasons to take an interest in the experiences that students in medical school in Mexico have had with unwanted pregnancy and abortion. First, the medical students provide a best-case scenario for adolescents wishing to avoid an unwanted pregnancy or an abortion. Other adolescents could scarcely be expected to have higher motivation or better access to information and services than young medical students have had. Education is one of the few key factors that contribute significantly to enhanced contraceptive use and pregnancy prevention. For example, a report issued in Mexico in 2001 indicated that $48 \%$ of illiterate women within stable unions were using some contraceptive method, in contrast to $75 \%$ of women who had completed at least 9 years of schooling (4). Second, studying unwanted pregnancy and abortion among Mexican medical stu- dents can help predict what future service providers and potential opinion leaders in the medical community will have as their background.

We chose to do our study at the School of Medicine of the National Autonomous University of Mexico (NAUM) (Universidad Nacional Autónoma de México, or UNAM), which is a public university located in Mexico City. With over 130000 students, the NAUM is the largest university in Latin America and also represents a sizable portion of the some one million students attending college in Mexico (5). The NAUM School of Medicine is the largest medical school in Mexico (6).

\section{METHODS}

In August 1998, with the approval of the Ethics Committee of the School of Medicine, we surveyed all 905 first-year students at the NAUM School of Medicine. Men and women completed separate, anonymous, self-administered questionnaires. The survey took 30 to 45 minutes to complete. The women students had a median and mean age of 18 years. Of the 587 women students, 578 of them (95\%) answered the questionnaire. Of those 578 completed questionnaires, 549 of them (93\%) were usable, that is, with all sections in the questionnaire fully answered.

The ad hoc Spanish instrument (available upon request) included 185 questions covering demographic data, current tobacco use, alcohol consumption in the preceding 12 months, use of contraceptive methods, attitudes regarding sexually transmitted infections, and such risk behavior practices as having a sexual partner in the preceding 3 months with whom they had not used a condom. The instrument also asked about the abuse of drugs that require a prescription but that can sometimes be purchased at pharmacies without obtaining that authorization.

Sexual practice questions covered age at the start of sexual activity among the women; number of sexual partners the women had had in the preceding 3 months; contraceptive use (particularly partner's condom use); women's prac- tice of anal sex with or without a condom; sexual partner(s) with AIDS; intravenous drug use among the women; heterosexual, homosexual, and bisexual practices among the women; and practice of or purchase of commercial sex by the women.

Cross-tabular analyses estimated the crude prevalence for each categorical and ordinal variable, and cross-tabular stratified analysis helped identify confounding and significant interactions among the variables. We analyzed the data using SPSS version 8.0 computer software (SPSS Inc., Chicago, Illinois, United States of America). We analyzed the statistical significance of count data involving categorical variables generally using chi-square $\left(c^{2}\right)$ tests, although in cases where cell size fell below 5, we used Fisher's exact test. All tests were two-tailed, and we set the significance level at $P \leq 0.05$.

\section{RESULTS}

Table 1 shows the demographic characteristics of the 549 women medical students who completely answered the survey questionnaire, in comparison to the characteristics of the general population of Mexican females aged 15 to $24(3,4,7)$. The female medical students had a mean age of 18.2 years (standard deviation of 2.3 years) and a mean of 13 years of schooling. Most of the women $(85 \%)$ were Catholic. The medical students had marital and religious patterns that were similar to those of the young general female Mexican population. One large difference, however, was the proportion who were full-time students. That was true for only $28 \%$ of the general female population aged 15 to 24 , in contrast to $92 \%$ of the medical students (the remainder of those respondents worked and took care of household duties in addition to studying). The history of sexual activity was also comparable between the female medical students and the general young Mexican female population: $22 \%$ of the study sample had been sexually active, vs. $20 \%$ of the comparably aged Mexican women. 
TABLE 1. Demographic characteristics of first-year female medical students at the National Autonomous University of Mexico (NAUM) in 1998 in comparison to the general population of Mexican females aged 15 to 24 in 1997

\begin{tabular}{|c|c|c|c|}
\hline \multirow[b]{2}{*}{ Demographic characteristic } & \multirow{2}{*}{$\begin{array}{l}\text { General population of } \\
\text { Mexican females } \\
(1997) \\
\%\end{array}$} & \multicolumn{2}{|c|}{$\begin{array}{c}\text { NAUM medical students } \\
\qquad(1998) \\
(n=549)\end{array}$} \\
\hline & & $\%$ & No. \\
\hline \multicolumn{4}{|l|}{ Religion } \\
\hline Catholic & 89.4 & 85.0 & 467 \\
\hline Protestant or Evangelical & 8.1 & 3.3 & 18 \\
\hline None & 2.8 & 8.4 & 46 \\
\hline Other & 0.7 & 3.3 & 18 \\
\hline \multicolumn{4}{|l|}{ Marital status } \\
\hline Single & 91.1 & 98.0 & 538 \\
\hline Married/Common-law & 8.5 & 1.8 & 10 \\
\hline Separated & 0.4 & 0.2 & 1 \\
\hline \multicolumn{4}{|l|}{ Occupation } \\
\hline Only studies & 27.9 & 91.8 & 504 \\
\hline Only works & 33.3 & 0 & 0 \\
\hline Household chores/student & 30.2 & 2.6 & 14 \\
\hline Studies and works & 6.8 & 5.6 & 31 \\
\hline Doesn't study or work & 1.7 & 0 & 0 \\
\hline \multicolumn{4}{|l|}{ Mother's education (yr) } \\
\hline 0 & 16.5 & 10.6 & 58 \\
\hline $1-6$ & 44.6 & 10.2 & 56 \\
\hline $7-9$ & 15.1 & 18.9 & 104 \\
\hline $10+$ & 23.8 & 60.3 & 331 \\
\hline \multicolumn{4}{|l|}{ Father's education (yr) } \\
\hline 0 & 11.5 & 11.1 & 61 \\
\hline $1-6$ & 43.1 & 0.5 & 3 \\
\hline $7-9$ & 17.1 & 15.9 & 87 \\
\hline $10+$ & 28.3 & 70.5 & 387 \\
\hline Missing & $N A^{c}$ & 2.0 & 11 \\
\hline \multicolumn{4}{|l|}{ Sexually active at some point } \\
\hline Yes & 20.3 & 21.9 & 120 \\
\hline No & 79.7 & 78.1 & 429 \\
\hline \multicolumn{4}{|l|}{ Contraceptive method currently used ${ }^{d}$} \\
\hline Pill & 15.8 & 18.0 & 18 \\
\hline Intrauterine device & 42.3 & 1.0 & 1 \\
\hline Injection & 9.7 & 1.0 & 1 \\
\hline Barrier methods ${ }^{e}$ & 0.1 & 8.0 & 8 \\
\hline Condom & 9.5 & 63.0 & 63 \\
\hline Bilateral tubal ligation & 6.5 & 1.0 & 1 \\
\hline Vasectomy (partner) & 0.6 & 1.0 & 1 \\
\hline Natural family planning ${ }^{\dagger}$ & 15.3 & 7.0 & 7 \\
\hline No current use of contraceptive methods ${ }^{g}$ & 15.7 & 16.7 & 20 \\
\hline Abortion (ever had) & 10.9 & 1.8 & 10 \\
\hline
\end{tabular}

a Source: México, Consejo Nacional de Población (7).

b Source: México, Instituto Nacional de Estadística, Geografía e Informática $(3,4)$.

c NA = not applicable

d Percentages indicated for contraceptive methods are based on the number of women who have ever used contraception (100 among the medical students).

e Barrier methods include spermicidal suppositories and ovules.

${ }^{f}$ Natural family planning includes the rhythm method and withdrawal.

9 Percentages indicated for no current use of contraceptive methods are based on the number of women who have been sexually active (120 among the medical students).

Table 2 shows the demographic characteristics of the study sample, classified by sexual activity status, contraceptive use, pregnancy history, and abortion history.

Condom use had clearly played a large role for the women medical stu- rently using contraception reported having a sexual partner with whom they had not used a condom during the preceding 3 months (data not shown in tables).

With respect to pregnancy, 19 women $(3.5 \%)$ from the sample of 549 medical students had been pregnant. Of these 19 women, 9 of them had continued with the pregnancy, while the other 10 reported having had an abortion. When asked on the questionnaire how many abortions they had had, 10 of the women $(2 \%)$ reported one or more: 8 reported one abortion, and 2 reported they had had two abortions. Although the questionnaire wording did not distinguish between spontaneous and induced abortions, we assumed that all 10 of the women were referring to induced abortions. That is because data from Mexico show that induced abortions mainly take place among young women (2), and it is common practice that when reproductive health surveys inquire about "abortion," the word is used as a synonym for induced abortion. All 10 of the women reporting an abortion stated that they had been using contraception at the time that they had become pregnant.

Current tobacco use was reported by 82 women (14.9\%), and alcohol consumption in the preceding 12 months was reported by 245 participants $(44.6 \%)$. The mean age at start of sexual activity was 16.8 years (standard deviation 1.7 years). One sexual partner in the preceding 3 months was reported by 56 women $(10.2 \%)$, while 14 stated they had not had sexual intercourse in the preceding 3 months. The practice of anal sex while using a condom was reported by 9 women $(1.6 \%)$, and without a condom by 5 of the women $(0.9 \%)$. Two women $(0.4 \%)$ reported having a sexual partner with AIDS. Intravenous drug use (heroin, opium) was reported by 2 women $(0.4 \%)$ (our questionnaire did not ask about their partner's drug use). Of the 120 women who had been sexually active at some point, 116 of them reported current heterosexual practices and 4 reported not being sexually active in the preceding 3 months. Data 
TABLE 2. Demographic characteristics of first-year female medical students at the National Autonomous University of Mexico (NAUM) in 1998, classified by sexual activity status, contraceptive use, pregnancy, and abortion

\begin{tabular}{|c|c|c|c|c|c|}
\hline Demographic characteristic & $\begin{array}{l}\text { All NAUM female } \\
\text { medical students } \\
\qquad(n=549)\end{array}$ & $\begin{array}{c}\text { Ever } \\
\text { sexually active } \\
(n=120)\end{array}$ & $\begin{array}{c}\text { Ever used } \\
\text { contraceptives } \\
(n=100)\end{array}$ & $\begin{array}{l}\text { Ever pregnant } \\
\qquad(n=19)\end{array}$ & $\begin{array}{l}\text { Ever had an } \\
\text { abortion } \\
(n=10)\end{array}$ \\
\hline Age (yr) (mean, standard deviation) & $18.2(2.3)$ & $19.3(4.4)$ & $19.4(4.4)$ & $22.4(6.9)$ & $21.5(7.5)$ \\
\hline \multicolumn{6}{|l|}{ Religion (no., \%) } \\
\hline Catholic & $467(85.0)$ & $95(79.2)^{a}$ & $78(78.0)^{\mathrm{a}}$ & $16(84.2)^{\mathrm{a}}$ & $8(80.0)$ \\
\hline Protestant or Evangelical & $18(3.3)$ & $4(3.3)^{a}$ & $3(3.0)^{a}$ & $0(0.0)^{a}$ & $0(0.0)$ \\
\hline None & $46(8.4)$ & $19(15.8)^{\mathrm{a}}$ & $17(17.0)^{\mathrm{a}}$ & $0(0.0)^{\mathrm{a}}$ & $2(20.0)$ \\
\hline Other & $18(3.3)$ & $2(1.7)^{a}$ & $2(2.0)^{a}$ & $3(15.8)^{a}$ & $0(0.0)$ \\
\hline \multicolumn{6}{|l|}{ Marital status (no., \%) } \\
\hline Single & $538(98.0)$ & $110(91.7)^{b}$ & $90(90.0)^{b}$ & $10(52.6)^{b}$ & $8(80.0)^{b}$ \\
\hline Married/Common-law & $10(1.8)$ & $10(8.3)^{\mathrm{b}}$ & $10(10.0)^{b}$ & $9(47.4)^{b}$ & $2(20.0)^{b}$ \\
\hline Separated & $1(0.2)$ & $0(0.0)^{b}$ & $0(0.0)^{\mathrm{b}}$ & $0(0.0)^{\mathrm{b}}$ & $0(0.0)^{b}$ \\
\hline \multicolumn{6}{|l|}{ Mother's education (no., \%) } \\
\hline $0 \mathrm{yr}$ & $58(10.6)$ & $6(5.0)^{b}$ & $4(4.0)^{b}$ & $2(10.5)^{a}$ & $0(0.0)$ \\
\hline $1-6 \mathrm{yr}$ & $56(10.2)$ & $2(1.7)^{b}$ & $1(1.0)^{b}$ & $0(0.0)^{a}$ & $0(0.0)$ \\
\hline $7-9 \mathrm{yr}$ & $104(18.9)$ & $25(20.8)^{b}$ & $20(20.0)^{b}$ & $5(26.3)^{a}$ & $3(30.0)$ \\
\hline $10-12 \mathrm{yr}$ & $123(22.4)$ & $34(28.3)^{b}$ & $29(29.0)^{b}$ & $6(31.6)^{a}$ & $2(20.0)$ \\
\hline $13-16 \mathrm{yr}$ & $137(25.0)$ & $31(25.3)^{b}$ & $26(26.0)^{b}$ & $4(21.0)^{a}$ & $3(30.0)$ \\
\hline $17+y r$ & 71 (12.9) & $22(18.3)^{b}$ & $20(20.0)^{b}$ & $2(10.5)^{a}$ & $2(20.0)$ \\
\hline \multicolumn{6}{|l|}{ Father's education (no., \%) } \\
\hline $0 \mathrm{yr}$ & $61(11.1)$ & $16(13.3)$ & $15(15.0)$ & $1(5.3)$ & $1(10.0)$ \\
\hline $1-6 \mathrm{yr}$ & $3(0.5)$ & $1(0.8)$ & $1(1.0)$ & $0(0.0)$ & $0(0.0)$ \\
\hline $7-9$ yr & $87(15.9)$ & $16(13.3)$ & $11(11.0)$ & $4(21.0)$ & $2(20.0)$ \\
\hline $10-12 \mathrm{yr}$ & $127(23.1)$ & $20(16.7)$ & $16(16.0)$ & $4(21.0)$ & $3(30.0)$ \\
\hline $13-16 \mathrm{yr}$ & 67 (12.2) & $15(12.5)$ & $13(13.0)$ & $3(15.8)$ & $1(10.0)$ \\
\hline $17+y r$ & $193(35.2)$ & $48(40.0)$ & $41(41.0)$ & $6(31.6)$ & $2(20.0)$ \\
\hline Missing & $11(2.0)$ & 4 (3.3) & $3(3.0)$ & $1(5.3)$ & $1(10.0)$ \\
\hline
\end{tabular}

a Differences in distribution as compared to total sample are statistically significant according to chi-square $\left(\chi^{2}\right)$ and Fisher's exact tests at the $P \leq 0.01$ level.

${ }^{b}$ Differences in distribution as compared to total sample are statistically significant according to chi-square $\left(\chi^{2}\right)$ and Fisher's exact tests at the $P \leq 0.001$ level.

on homosexual and bisexual practices are not available because the women did not answer this question. None of the study respondents reported engaging in commercial sex work (either buying or selling).

\section{DISCUSSION}

The rates of sexual activity reported by the sample of medical school students and by the women of the same age in the general population in Mexico were roughly equal, $22 \%$ vs. $20 \%$. However, only $2 \%$ of the female medical students reported that they had ever had an abortion, compared with $11 \%$ of women of the same ages in the general population. In total, only $3.5 \%$ of the medical students had ever been pregnant. We lack comparable information on the pregnancy rate for women of a similar age in the general Mexican population.
Though the rate of abortion for the women medical school students was substantially lower than the rate among women of the same age group in the general Mexican population, it is interesting to note that at the time of the survey the medical students were more often using less effective contraception (e.g., barrier methods) than were their counterparts in the general population (with, e.g., higher use of the intrauterine device, injections, and tubal ligation). However, more women in the general population were using natural family planning than was true for the female medical students in our sample, $15 \%$ vs. $7 \%$.

At the time of the survey, half of the women medical students then using contraception reported having a sexual partner with whom they had not used a condom during the preceding 3 months. Consistent condom use has been described among adolescents and college students in surveys from other countries (8-16). For example, a sustained increase in condom use over the 1998-1994 period was documented in samples of Australian students aged 18-19 (12), with condoms becoming the contraceptive method most frequently used and an effective means of preventing sexually transmitted diseases and avoiding an abortion.

A recent study of rates of induced abortion among 199 women aged 18 to 24 in Mexico City found that 39 of them $(20 \%)$ had experienced an unintended pregnancy (14). Of those 39, 9 of them $(23 \%)$ had attempted to terminate the pregnancy, and 4 of the 39 $(10 \%)$ had succeeded in ending the pregnancy. While our NAUM survey did not distinguish between intended and unintended pregnancies, it did reveal that more than half (10 of the 19 , or $53 \%$ ) of the pregnancies among the medical students ended in abortion. This indicates that medical students were far more likely to find effective 
means to terminate a pregnancy than were women of the same age in the general population. As mentioned earlier, more exposure to medical information is assumed to be critical in changing contraception perceptions, contraceptive use, and abortion practices. As might be expected, the parents of medical school students were more highly educated than were the parents of women of the same age in the general population (Table 1), another indication of the role that education levels play in pregnancy and abortion.

When the NAUM survey was conducted, the marital status of the women who had chosen to continue their pregnancy was different from the status of the women who had had an abortion. Of the 19 pregnancies among the medical student sample, 10 of them had occurred among women who were single at the time of the survey, and the other 9 had occurred among women who were married when the survey was done. (We did not record the marital status of the women at the time of the abortion.) It is noteworthy that the one group of women decided to combine their pregnancy and their ongoing education in a society where pregnant adolescents commonly see motherhood as their main form of self-fulfillment (17). This is a further indication that the women medical students were highly motivated in their desire to enter a profession that has traditionally been male dominated.

Studies on the use of emergency contraception and medical abortion among middle-class women and men of reproductive age in Mexico City have found that more education is associated with increased contraceptive knowledge and use as well as greater support for abortion methods that do not involve surgical intervention, that provide more privacy, that are less painful, and that have lower risk of uterine perforation and of infertility (18).

The public dissemination of information is critical in promoting the use of new methods for avoiding abortions or ending a pregnancy. Nevertheless, barriers to health providers and clients communicating with each other on reproductive and sexual health issues persist in Mexico (18). Education alone is not adequate in ensuring that physicians provide the abortion services that comply with the extenuating circumstances under current laws and are thus authorized.

Various researchers have looked at the attitudes that physicians in Mexico have towards the practice of abortion. A large majority of health care professionals avoid public pronouncements about a topic that they perceive as being too controversial $(19,20)$, while a minority have publicly voiced their discontent with the number of women who die each year due to abortions (21). Female physicians tend to adopt a more conservative stand than their male counterparts do towards the practice of abortion, proving that just being a woman is not sufficient to make a person more sensitive to the issue of abortion (19). These findings concerning physicians' attitudes are in line with qualitative research results that indicate that dominant views of femininity and masculinity influence sexual initiation and adolescent sexuality in Mexico (22).

Various factors influence physicians' provision of abortion services that are authorized under existing legislation. The recent liberalization of abortion laws in Mexico City has played a role, as had the growth of abortion as a public health issue in Mexico following the United Nations Conference on Population and Development held in Cairo in 1994 (23). Public opinion is growing in favor of increasing the options permitted for women under the specific circumstances envisioned by current law (24) as well as allowing women to decide when and if to terminate a pregnancy (25). A recent survey in Mexico found that $70 \%$ of the persons interviewed believed that an abortion should be performed when the pregnancy resulted from rape or when the health or life of the woman was endangered. Some $50 \%$ supported abortion in the case of congenital abnormalities, but fewer than $25 \%$ because the woman was under 21 years old, was single, or lacked the economic means to support the child, or because the contraceptive method had failed (25).

We believe that the results of our survey indicate that conditions are favorable for physicians to develop greater sensitivity in the treatment of abortion as a public health problem. The growing number of female students attending the NAUM School of Medicine could contribute to a different perception of abortion and of contraception. However, for these women's views to translate into medical practice after they have graduated and to increase the probability that these women will become advocates for considering abortion a public health problem, there is a need for reproductive health to become a part of the medical school curriculum. If that does not happen, some female students might continue to take a more conservative stance than their male counterparts do, as the scientific literature has indicated is now the case.

Based on our results, we would suggest several possible areas for further research. Income is a key factor in accessing safe abortion in countries where the procedure remains illegal. Therefore, future studies could explore the conditions that first-year female medical students have encountered when seeking abortions as well as the methods to which they have resorted. It would also be appropriate to explore how these women's experiences have changed their perceptions of abortion and the extent to which they would be willing to offer alternatives to their less-privileged peers or to older women seeking abortion.

Acknowledgements. This work was partly supported by the School of Medicine of the National Autonomous University of Mexico, Mexico City; The Population Council Regional Office for Latin America and the Caribbean; and the National Council of Science and Technology of Mexico (CONACYT 34174-M, Claudia Díaz-Olavarrieta). The authors thank Noemi Ehrenfeld and Carlos Welti for technical advice and Abigail Norris Turner for editorial assistance. 


\section{REFERENCES}

1. Blum RW. Global trends in adolescent health. JAMA 1991;265:2711-2719.

2. Alan Guttmacher Institute. Aborto clandestino: una realidad latinoamericana. New York: Alan Guttmacher Institute; 1994.

3. México, Instituto Nacional de Estadística, Geografía e Informática. Hombres y mujeres de México. México, D.F.: INEGI; 2001.

4. México, Instituto Nacional de Estadística, Geografía e Informática. Estadísticas educativas de hombres y mujeres. México, D.F.: INEGI; 2001.

5. Asociación Nacional de Universidades e Institutos de Educación Superior. Anuario estadístico. Población escolar de licenciatura en universidades e institutos tecnológicos. México, D.F.: ANUIES; 1998.

6. Universidad Nacional Autónoma de México. Agenda estadística. México, D.F.: UNAM; 2002.

7. México, Consejo Nacional de Población. Situación actual de las y los jóvenes en México. Diagnóstico sociodemográfico. México, D.F.: CONAPO; 2000. (Serie Documentos Técnicos).

8. Lara D, Strickler J, Díaz-Olavarrieta C, Ellertson C. Measuring induced abortion in Mexico: a comparison of four methodologies. Sociol Methods Res. (Forthcoming 2003).

9. Dilorio C, Dudley WN, Lehr S, Soet JE. Correlates of safer sex communication among college students. J Adv Nurs 2000;32(3):658-665.

10. Peltzer K. Factors affecting condom use among South African university students. East Afr Med J 2000;77(1):46-52.
11. Peltzer K. Knowledge and practice of condom use among first year students at University of the North, South Africa. Curationis 2001; 24(1):53-57.

12. Rodden P, Crawford J, Kippax S, French J. Sexual practice and understanding of safe sex: assessing change among 18- to 19-yearold Australian tertiary students, 1988 to 1994. Aust N Z J Public Health 1996;20(6):643-649.

13. Zhang L, Gao X, Dong Z, Tan Y, Wu Z. Premarital sexual activities among students in a university in Beijing, China. Sex Transm Dis 2002;29(4):212-215.

14. Nuñez-Urquiza RM, Hernández-Prado B, García-Barrios C, González D, Walquer D. Embarazo no deseado en adolescentes, y utilización de métodos anticonceptivos posparto. Salud Publica Mex 2003;45(1):92-102.

15. Turner $\mathrm{CF}, \mathrm{Ku} \mathrm{L}$, Rogers SM, Lindberg LD, Pleck JH, Sonenstein FL. Adolescent sexual behavior, drug use, and violence: increased reporting with computer survey technology. Science 1998;280(5365):867-873.

16. Crosby R, Leichliter JS, Brackbill R. Longitudinal prediction of sexually transmitted diseases among adolescents: results from a national survey. Am J Prev Med 2000;18(4):312317.

17. Ortiz-Ortega A, Amuchástegui A, Rivas M. Because they were born from me. In: Petchesky R, Judd K. Negotiating reproductive rights. London: Zed Books; 1998. Pp. 145-179.

18. Gould H, Ellertson C, Corona G. Knowledge and attitudes about the differences between emergency contraception and medical abortion among middle-class women and men of reproductive age in Mexico City. Contraception 2002;66(6):417-426.

19. González de León Aguirre D, Salinas Urbina AA. Los médicos en formación y el aborto: opinión de estudiantes de medicina en la Ciudad de México. Cad Saude Publica 1997;13(2): 227-236.

20. González de León-Aguirre D. Los médicos y el aborto. Salud Publica Mex 1995;37(3):248255.

21. Ortiz-Ortega A. Razones y pasiones en torno al aborto. México, D.F.: The Population Council, EDAMEX; 1994.

22. Amuchástegui A. Virginidad e iniciación sexual en México. México, D.F.: The Population Council, EDAMEX; 2000.

23. Ortiz-Ortega A. Si los hombres se embarazaran, ¿el aborto sería legal? México, D.F.: The Population Council, EDAMEX; 2000.

24. Núñez-Fernández L, Shrader-Cox E, Benson J. Encuesta de opinión sobre el aborto en la Ciudad de México. Salud Publica Mex 1994;36(1): 36-45.

25. García S, Becker D. ¿Qué piensan y qué opinan los mexicanos sobre el aborto? Resultados de una encuesta nacional sobre opinión pública. México, D.F.: The Population Council; 2001.

Manuscript received 3 June 2002. Revised manuscript ac-

RESUMEN Objetivo. Con entrenamiento adecuado, los estudiantes de medicina pueden convertirse en líderes de opinión con futura injerencia sobre las políticas de salud, así como ayudar al público a entender las consecuencias de los embarazos indeseados y del aborto. El objetivo del presente estudio ha sido examinar la frecuencia del embarazo indeseado y del aborto provocado en mujeres de primer año de la carrera de medicina en una de las principales universidades de México, D.F., y comparar las experiencias de esas mujeres con las de la población general de mujeres mexicanas entre los 15 y 24 años de edad.

Métodos. En 1998 hicimos una encuesta transversal de todas las estudiantes de primer año de medicina de la Universidad Autónoma de México, que es la universidad más grande de América Latina. Examinamos un total de 549 encuestas.

Resultados. De las 549 mujeres encuestadas, 120 (22\%) habían tenido actividad sexual en algún momento. De esas 120 estudiantes que habían sido activas sexualmente, $100(83 \%)$ habían usado un método anticonceptivo alguna vez y 19 de las $120(16 \%)$ habían estado embarazadas. De estas últimas 19 mujeres, 10 se habían sometido a un aborto ilegal (en México el aborto siempre es ilegal salvo en circunstancias extenuantes muy contadas). La frecuencia declarada de aborto entre las estudiantes de medicina, que fue de $2 \%$, fue muy baja en comparación con la frecuencia de $11 \%$ hallada en mujeres de la misma edad en la población mexicana en general.

Conclusiones. La menor incidencia del aborto entre las estudiantes de medicina revela que cuando las jóvenes mexicanas tienen a su alcance información de orden médico y el firme propósito de evitar el embarazo indeseado y el aborto, lo pueden lograr. 